\title{
Evaluating Safeguards in a Conservation Incentive Program: Participation, Consent, and Benefit Sharing in Indigenous Communities of the Ecuadorian Amazon
}

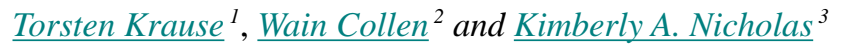

\begin{abstract}
Critics suggest that Reducing Emissions from Deforestation and forest Degradation (REDD+) may not generate improvements in well-being for participating stakeholders, and may in fact undermine indigenous rights. To ensure positive social benefits from REDD+ projects, the United Nations REDD Programme has proposed core safeguards, including local stakeholder participation; free, prior, and informed consent; and equitable distribution of benefits. However, there is little experience to date in implementing and evaluating these safeguards. We apply these core safeguards as a framework to study how people in indigenous communities in the Ecuadorian Amazon perceive and benefit from Programa Socio Bosque, a conservation incentive program in Ecuador's national REDD+ Programme portfolio. We interviewed 101 individuals in five communities that had participated in the Programa Socio Bosque for at least 18 months. Close to $80 \%$ of respondents reported that the decision to join Socio Bosque was made democratically, that they were familiar with the conservation goals of Socio Bosque, and that they were aware which area their community had selected for conservation. However, only $17 \%$ were familiar with the overall terms of the conservation agreement, implying that they were either not fully informed of or did not fully understand what they were consenting to in joining the program. Although the terms of the program require a community investment plan to be democratically developed by community members, less than half of respondents were aware of the existence of the investment plan, and fewer than $20 \%$ had participated in its development. The majority of respondents (61\%) reported that they did not know the amount of incentives that their community currently receives, and only $44 \%$ stated that incentives were managed democratically in communal assemblies. Moreover, although a slight majority (53\%) said they had noticed benefits to the community from participating in Socio Bosque, the majority (57\%) said their family had not received any benefits. These results demonstrate a need to strengthen inclusive participation, better inform participants about program design, and improve the management of incentives within communities if incentive-based conservation programs are to achieve their social development and environmental goals.
\end{abstract}

Key Words: benefit distribution; deforestation; Ecuador; forest governance; Payment for Ecosystem Services; Programa Socio Bosque; REDD+; safeguards

\section{INTRODUCTION}

Deforestation and forest degradation are the second largest sources of anthropogenic greenhouse gas emissions (Achard et al. 2004, Persson and Azar 2007, van der Werf et al. 2009). Forests, especially in the tropics, are also an essential biodiversity habitat (Myers 1988, Myers et al. 2000, Pearce 2007) and an important resource for local livelihoods (Shvidenko et al. 2005, FAO 2011). Command and control measures, as well as traditional conservation efforts, have frequently failed in solving environmental problems and protecting biodiversity (MEA 2005, Pearce 2005, Armsworth et al. 2007). The alternative environmental problem-solving strategy of using market-based instruments (Jones-Walters and Mulder 2009, TEEB 2010), such as payments for ecosystem services (PES) (Wunder 2005), has been applied on national scales in Mexico and Costa Rica (Engel et al. 2008, Pagiola 2008, McAfee and Shapiro 2010), and more recently, Ecuador (de Koning et al. 2011).
Reducing Emissions from Deforestation and forest Degradation, plus the conservation and enhancement of carbon stocks and the sustainable management of forests (REDD+) is a proposed global PES scheme primarily for the mitigation of climate change (Pistorius 2012). REDD+ faces several technical, social, legal, political, economic, and environmental challenges alongside a broader critique about its legitimacy (Gibbs et al. 2007, Skutsch and Van Laake 2008, Corbera and Schroeder 2011, Hufty and Haakenstad 2011, Merger et al. 2011, Angelsen et al. 2012, Corbera 2012). However, it is also expected to promote social and environmental co-benefits (Busch et al. 2010, McDermott et al. 2012, Visseren-Hamakers et al. 2012), but there remains a risk that REDD+ may undermine past achievements in decentralized forest governance (Phelps et al. 2010), and may in fact weaken local and indigenous rights (Van Dam 2011).

\footnotetext{
${ }^{1}$ Lund University Centre of Excellence for Integration of Social and Natural Dimensions of Sustainability, ${ }^{2}$ International Institute for Industrial Environmental Economics, ${ }^{3}$ Lund University Centre for Sustainability Studies
} 
Local stakeholder participation represents the most important pillar of any global forest protection mechanism if a post-2012 climate regime is to be effective and equitable (Daviet et al. 2011). Therefore, designing and implementing REDD+ projects requires participation of indigenous and local populations (Skutsch and Van Laake 2008). International safeguards are proposed to counteract potential negative social and environmental outcomes of prospective REDD+ projects. Currently, there are various safeguard initiatives for global REDD+ project implementation (Moss and Nussbaum 2011, McDermott et al. 2012). These include the UN-REDD Programme Social and Environmental Principles and Criteria (UN-REDD 2011), the Forest Carbon Partnership Facility (FCPF) Readiness Fund Common Approach to Environmental and Social Safeguards for Multiple Delivery Partners (FCPF 2011), and the REDD+ Social and Environmental Standards (CCBA and CARE 2010).

Decision 1 adopted by the United Nations Framework Convention on Climate Change (2011) at the 16th Conference of the Parties in Durban (COP 16) similarly focuses on social and environmental safeguards, including full and effective stakeholder participation and the respecting of indigenous peoples' rights. More specifically, the UN-REDD Social and Environmental Principles and Criteria (UN-REDD 2011) specify that REDD+ projects should achieve full and effective participation of indigenous peoples; require free, prior, and informed consent (FPIC); and ensure equitable benefit sharing (Table 1). Consent that meets FPIC standards is free of coercion, intimidation, and manipulation, is obtained prior to the commencement of project activities, and is informed through access to necessary information, such as the purpose, design, terms, duration, and location of the project, in order to make the decision (Herbertson et al. 2009, Anderson 2011, Daviet et al. 2011, FCPF and UN-REDD 2011).

Table 1. Selected social and environmental principles and criteria guiding the implementation of REDD projects, developed by the UN-REDD Programme (2011).

UN-REDD Social and Environmental Principles and Criteria

Principle 1-Apply norms of democratic governance

- Criterion 4: Ensure the full and effective participation of relevant stakeholders, in particular, indigenous peoples, and other forestdependent communities, with special attention to the most vulnerable and marginalized groups

Principle 2-Respect and protect stakeholder rights

- Criterion 9: Seek free, prior, and informed consent of indigenous peoples and other forest-dependent communities and respect and uphold the decision taken (whether consent is given or withheld)

Principle 3 - Promote and enhance forests' contribution to sustainable livelihoods

- Criterion 12: Ensure equitable, nondiscriminatory, and transparent benefit sharing and distribution among relevant stakeholders with special attention to the most vulnerable and marginalized groups
Indigenous peoples play an indispensable role in REDD+ (Ricketts et al. 2010), especially in Latin America where indigenous territories cover large areas of Amazonian rain forests (Benavides 2009, Van Dam 2011). Although the assumption that indigenous people are inherently good forest stewards should not be taken at face value ( $\mathrm{Lu} \mathrm{2006),} \mathrm{these}$ groups are often better at protecting forests than national parks or other protected areas (Nelson and Chomitz 2009), and policies for incentivizing forest conservation in these territories can provide additional support (Gray et al. 2007). Respecting indigenous rights and adhering to international laws and declarations is imperative for any international and national REDD+ policy strategy (FCPF and UN-REDD 2011) and projects at the subnational level, such as the establishment of national parks or the reduction of subsidies for cattle ranching.

Proponents of the traditional PES approach argue that economic incentives are essential for conservation (Wunder 2000); however, this is equitable only if the relevant stakeholders, i.e., the right holders who bear the cost of conservation, directly benefit and receive a fair incentive for their participation (Costenbader 2009). Due to heterogeneous community structures, it is important to study the fair benefit distribution not only among different stakeholders (Costenbader 2011) but also within stakeholder groups. Some studies have discussed benefit sharing among local stakeholders and communities (Corbera et al. 2007, Peskett 2011, Luttrell et al. 2012). However, only a few studies have analyzed benefit distribution in PES or REDD+ pilot projects (Caplow et al. 2011), including direct and indirect benefits, within the stakeholder group that bears the cost of conservation (Corbera et al. 2007), and how social safeguards could be achieved in practice.

Ecuador has stated its intentions to participate in a global REDD+ mechanism and has been a full member of UN-REDD since 2011, from which it receives financial support (MAE 2012). We examine the Ecuadorian Programa Socio Bosque (PSB), hereafter also referred to as Socio Bosque, meaning Forest Partner, which is an incentive policy mechanism for ecosystem conservation. Although PSB is not a pure REDD+ program because it does not require proof of additionality in reduced deforestation and it also includes nonforest ecosystems, it is an important element of Ecuador's national REDD+ Programme (ENREDD) through the forest governance model under the Ministry of Environment (MAE 2011, 2012). Apart from establishing a system for forest reporting and monitoring, and for implementating policies and cost-effective measures to reduce deforestation and degradation, ENREDD has the goal of complying with safeguards and ensuring multiple benefits, i.e., establishing a fair and equitable distribution mechanism for REDD+ incentives by 2013 (Chíu and Carríon 2011, MAE 2012), and international safeguards are being adapted to the national 
context (Lhumea 2011, personal communication). Official communication and initial analyses argue that PSB generates significant livelihood benefits from the payments transferred to participating communities (de Koning et al. 2011), which totaled almost US\$1.5 million for all communities participating in PSB in the Amazon region in 2011 (PSB 2011). In February 2011, Socio Bosque began employing staff to support financial management and monitor the use of the incentives in participating communities. However, no systematic local-level evaluation of participation, informed consent, and benefit sharing in the local communities has yet been undertaken. A recent report supports the claim that Socio Bosque presents an opportunity to inform and improve the development of safeguards for the Ecuadorian context (USAID 2012).

We present empirical data from interviews with members of five indigenous communities participating in Socio Bosque in the Amazon region of Ecuador. Assessing compliance with important REDD+ safeguards ex-post, i.e., in an already functioning program like Socio Bosque, can provide valuable insights for improved implementation and monitoring of national REDD+ safeguards. We focus on the individual level of respondent's participation in collective decision-making processes; their knowledge about the terms of the conservation agreements, such as the duration and location of conservation areas, as a prerequisite for informed consent; and perceptions and attitudes towards the current benefit distribution. The safeguards framework (Table 1) guides the Results section, where we present the findings from our interviews, and the Discussion. In the Conclusion section, we present our recommendations based on our main findings.

\section{Background to Ecuador's Socio Bosque program}

The government of Ecuador launched Socio Bosque in September 2008, in anticipation of the prospects of an international REDD+ mechanism, and to support environmental protection, poverty reduction, and climate change adaptation and mitigation goals stipulated in the national development plan (SENPLADES 2009). The objectives of Socio Bosque are to reduce deforestation, protect biodiversity, provide hydrological services, and alleviate poverty and promote development in rural areas (MAE 2008). Participants are either private landowners or communities that own land collectively, most of which are indigenous communities; they receive biannual incentives disbursed to their bank account based on the area of native ecosystems protected (Krause and Loft 2013). Participants have to comply with a number of terms in the 20-year conservation agreement. These include an agreement not to change the vegetation land cover; to report any changes to it, either natural (e.g., from fire or storm) or through invasion or illegal logging by third parties; not to hunt for commercial purposes; and to adequately mark the conservation area (MAE 2008). Communities may have their own rules for the conservation area in addition to those specified by the agreement terms, such as a complete restriction of hunting and fishing, including for subsistence purposes.

An estimated 6.8 million ha, or 65\% of Ecuador's forest area, are under local and indigenous ownership, mostly in the Amazon region (ITTO 2009, Bertzky et al. 2010, Chíu and Carríon 2011), which underlines their importance for forest conservation. There are 14 recognized indigenous nationalities in Ecuador, and depending on which definition is used, somewhere between 7\% (INEC 2010) and 40\% of the population is considered to be indigenous (Becker 2010). In the Ecuadorian Amazon, the Kichwa are the largest indigenous group (Bremner and Lu 2006).

Community assemblies are the most common process for making decisions, particularly for land and resource use since these are collectively owned. The terms of Socio Bosque also require community investment plans that detail how the incentives will be used for the benefit of the community (de Koning et al.2011). These investment plans must be developed by community members in democratic community assemblies, updated every year, and approved by the PSB office (MAE 2009).

Since the implementation of Socio Bosque in September 2008, more than 880,000 ha, most of which are covered by tropical forests, and almost 90,000 individual and collective beneficiaries have been enrolled in the program (PSB 2011). Indigenous communities in the Amazon region are a critical stakeholder group for Socio Bosque; at the time of writing, there were 21,000 beneficiaries in 35 collective contracts in the Amazon region, representing $76 \%$ of all land under PSB conservation in Ecuador (PSB 2011).

\section{METHODS AND STUDY SITE}

We chose to study the Amazon region due to its importance for Socio Bosque and due to the relevance of tropical forests for REDD+, and because the region is experiencing ongoing deforestation and forest degradation as a result of multiple pressures on the land, such as oil production, illegal logging, and agricultural expansion (Mena et al. 2006, Finer et al. 2008). The Amazon is a region of great biodiversity (Mittermeier et al. 2003) and covers almost half the total area of Ecuador. The average population density in this region is low, with five inhabitants per square kilometer (MAE 2011). The vegetation is marked by wet closed-canopy evergreen, semi-deciduous tropical, and natural bamboo-dominated forests (Stern and Kernan 2011).

The study was conducted in two phases of fieldwork. In November-December 2010, we established contacts, tested a pilot questionnaire in one community, and used in-depth interviews with government officials, academic experts, and nongovernmental organizations to understand the context of Socio Bosque's work in the region and to further develop 
Table 2. Community demographics and information. Source: PSB (2011).

\begin{tabular}{lccccc}
\hline \hline Community & $\mathrm{A}$ & $\mathrm{B}$ & $\mathrm{C}$ & $\mathrm{D}$ & $\mathrm{E}$ \\
\hline Date of joining PSB & 2009 & 2009 & 2008 & 2008 & 2008 \\
Estimated total population & $<400$ & $>5000$ & $400-600$ & $400-600$ & $400-600$ \\
Size of conservation area (ha) & $2000-3000$ & $>10,000$ & $2000-3000$ & $2000-3000$ & $<2000$ \\
Incentive per year in US\$ & $10,000-20,000$ & $30,000-40,000$ & $10,000-20,000$ & $10,000-20,000$ & $10,000-20,000$ \\
(2011) & & & & 7 & 22 \\
Interviews: total number & 20 & 34 & 4 & 3 & 9 \\
Interviews: number of women & 10 & $6(2)$ & 0 & 0 & $7(5)$ \\
Interviews: numbers of & $9(6)$ & & & & \\
nonsocios (number of women) & & & & &
\end{tabular}

interview questions. The second research step was undertaken in June-July 2011, when we conducted a total of 101 structured interviews in five indigenous Kichwa communities (Table 2). Interviews were conducted in three communities in the provinces of Napo (referred to here, for anonymity, as Communities A, B, and E), and two communities in Sucumbíos (Communities $\mathrm{C}$ and D). Prior to conducting interviews, we visited each community to introduce the research and its purpose to the community members and leader, and to gain their permission to conduct interviews. Where possible, we did so at a communal meeting $(N=3)$, and otherwise through local help by at least one community member who assisted in introducing the researchers and facilitated access to individual community members $(N=2)$.

Purposeful sampling of communities was done based on the time of enrollment in PSB (at least one and a half years prior to our interviews), the ecosystem under conservation being rain forest, and the ease of access via roads. Based on the length of time the communities had been enrolled in the program, they had each received at least three rounds of incentives, which allowed us to identify issues related to the use of incentives and to evaluate the impacts of participation in PSB. The communities varied widely in their sizes, from a small village of less than 400 people (Community A) to a large community of more than 5000 , with a five-fold range in the size of the conservation areas (Table 2). Community B was the largest in terms of population, incentives received, and conservation area, and was comparatively difficult to access. Communities $\mathrm{C}$ and $\mathrm{D}$ were neighboring communities in an area affected by oil production and in which land available for agriculture was becoming increasingly scarce. Community E had a relatively small conservation area that was threatened by the expanding cultivation of naranjilla fruit. Communities $\mathrm{A}$ and $\mathrm{E}$ had dedicated part of their territory as a communal reserve before joining Socio Bosque, and had logging, fishing, or hunting restrictions in place for those areas.

Respondents in the communities were selected using random sampling of adults over 18 years of age. We were particularly interested in the accounts, participation, and perceptions of community members who did not hold a political position.
Therefore, we did not interview community leaders, whom we previously experienced to be more biased in favor of PSB. Before the interviews, respondents received clarification about the purpose and the use of collected information, and were assured individual anonymity. Interviews were conducted primarily in Spanish, with the occasional help of a Kichwa translator to clarify questions when needed.

We chose to use a particular set of indicators at the individual level to get at the issues of benefit sharing, participation, and consent, although participation and consent take place in community meetings and in the form of collective action. Paying attention to individual knowledge helps to evaluate the effectiveness of local collective decision-making institutions. Thus, our analysis goes beyond evaluating the number of community assemblies as an indicator of effective participation and looks at perceptions at the individual level.

The interviews focused on the participation of individual community members in the process of collective decisionmaking through local institutions, the individual's knowledge about elements of the conservation agreement to determine informed consent, including the workings of Socio Bosque and land use rules for the conservation area, and the perception of community members regarding the distribution of benefits and costs from Socio Bosque. We also collected demographic information, including respondents' formal community membership status. In all the interviewed communities, people need to obtain full membership status (called "socio"meaning partner or member) to vote on important communal decisions, such as joining Socio Bosque, and to be assigned their own land for establishing forest gardens. This process is determined differently by each community, and is based on a person's age or time of residence in the community, as well as personal character and conduct.

Most questions were asked on a three-point scale, with possible answers "Yes," "No," and "Don't know"; other questions that evaluated knowledge of specific information were later coded to "Yes" if the respondent knew the correct answer, or "No" if they did not. To measure people's perception of their own participation in decision-making concerning the use of the incentives, and the associated level 
Fig. 1. Interview questions and answers related to full and effective participation for all respondents (Level 1), by individual communities (Level 2), and for women and non-socios within each community (Level 3). The percentages are relative to the number of respondents in that group (i.e., total respondents in each community for Level 2, or total women or non-socios in each community for Level 3). Means across all communities for the total number of women and non-socios are shown in gray columns. The percentages for each group are highlighted in green when $\geq 20 \%$ higher than the global mean (Level 1), or yellow when $\geq 20 \%$ lower than the global mean. Bold font indicates the aggregated "Yes" answers on which the disaggregated answers for each community are based. NA = not applicable.

\begin{tabular}{|c|c|c|c|c|c|c|c|c|c|c|c|c|c|c|c|c|c|c|c|c|c|c|c|}
\hline \multirow{4}{*}{ Ruestion } & \multicolumn{4}{|c|}{ Level 1} & \multicolumn{5}{|c|}{ Level 2} & \multicolumn{14}{|c|}{ Level 3} \\
\hline & \multirow{2}{*}{\multicolumn{4}{|c|}{ All respondents }} & \multicolumn{19}{|c|}{ Only Yes answers } \\
\hline & & & & & \multicolumn{5}{|c|}{ Community } & \multicolumn{7}{|c|}{ Women } & \multicolumn{7}{|c|}{ Non-socios } \\
\hline & $\mathrm{N}$ & Yes & No & $\begin{array}{l}\text { Don't } \\
\text { know }\end{array}$ & A & B & C & $\mathrm{D}$ & E & A & B & $\mathrm{C}$ & $\mathrm{D}$ & E & $\mathrm{N}$ & Yes & A & B & $\mathrm{c}$ & D & E & $\mathrm{N}$ & Yes \\
\hline $\begin{array}{l}\text { Did you } \\
\text { participate in the } \\
\text { decision to join } \\
\text { Socio Bosque? }\end{array}$ & 97 & $66 \%$ & $33 \%$ & $1 \%$ & $70 \%$ & $40 \%$ & $83 \%$ & $86 \%$ & $82 \%$ & $50 \%$ & $18 \%$ & $75 \%$ & $100 \%$ & $67 \%$ & 37 & $51 \%$ & $44 \%$ & $17 \%$ & NA & NA & $57 \%$ & 22 & $41 \%$ \\
\hline $\begin{array}{l}\text { Do you know } \\
\text { about the } \\
\text { existence of the } \\
\text { investment plan? }\end{array}$ & 98 & $39 \%$ & $39 \%$ & $1 \%$ & $35 \%$ & $25 \%$ & $44 \%$ & $57 \%$ & $52 \%$ & $30 \%$ & $33 \%$ & $0 \%$ & $67 \%$ & $13 \%$ & 37 & $27 \%$ & $33 \%$ & $17 \%$ & NA & $\mathrm{NA}$ & $17 \%$ & 21 & $24 \%$ \\
\hline \multirow[t]{2}{*}{$\begin{array}{l}\text { If yes, did you } \\
\text { participate in the } \\
\text { decision of what } \\
\text { to include in the } \\
\text { investment plan? }\end{array}$} & 38 & $53 \%$ & $47 \%$ & $0 \%$ & $43 \%$ & $0 \%$ & $63 \%$ & $75 \%$ & $82 \%$ & $0 \%$ & $0 \%$ & $0 \%$ & $50 \%$ & $100 \%$ & 10 & $20 \%$ & $33 \%$ & $0 \%$ & NA & NA & $0 \%$ & 5 & $20 \%$ \\
\hline & $\mathrm{N}$ & Assembly & Leaders & $\begin{array}{l}\text { Don't } \\
\text { know } \\
\text { / other }\end{array}$ & \multicolumn{19}{|c|}{ Only assembly answers } \\
\hline $\begin{array}{l}\text { How was the } \\
\text { decision to join } \\
\text { Socio Bosque } \\
\text { taken? }\end{array}$ & 99 & $81 \%$ & $6 \%$ & $13 \%$ & $95 \%$ & $56 \%$ & $89 \%$ & $86 \%$ & $95 \%$ & $90 \%$ & $58 \%$ & $75 \%$ & $100 \%$ & $100 \%$ & 38 & $82 \%$ & $89 \%$ & $50 \%$ & NA & NA & $100 \%$ & 22 & $82 \%$ \\
\hline $\begin{array}{l}\text { How was the } \\
\text { decision on } \\
\text { which area for } \\
\text { conservation to } \\
\text { choose taken? }\end{array}$ & 96 & $84 \%$ & $8 \%$ & $7 \%$ & $100 \%$ & $77 \%$ & $71 \%$ & $100 \%$ & $86 \%$ & $100 \%$ & $82 \%$ & $33 \%$ & $100 \%$ & $67 \%$ & 36 & $81 \%$ & $90 \%$ & $67 \%$ & NA & NA & $86 \%$ & 22 & $86 \%$ \\
\hline $\begin{array}{l}\text { In your } \\
\text { community, what } \\
\text { is the process to } \\
\text { manage the Socio } \\
\text { Bosque } \\
\text { incentives? }\end{array}$ & 95 & $44 \%$ & $32 \%$ & $20 \%$ & $65 \%$ & $19 \%$ & $39 \%$ & $71 \%$ & $57 \%$ & $80 \%$ & $17 \%$ & $0 \%$ & $67 \%$ & $63 \%$ & 37 & $46 \%$ & $78 \%$ & $33 \%$ & NA & NA & $50 \%$ & 21 & $57 \%$ \\
\hline
\end{tabular}

of information they had about incentives, we asked respondents to rate their participation or information on a three-point scale from "a lot" to "a little" to "nothing." The three-point scale was chosen for simplicity and ease of understanding. The data we obtained were transcribed from paper questionnaires and coded for analysis using Excel.

Responses were aggregated at three levels: (1) an overall mean of all respondents from every community, (2) the mean answer in each of the five communities, and (3) the mean answer for two groups, women and non-socios, across all communities. The mean was taken on a percentage basis of how many respondents answered "Yes" to each question to allow comparison between questions and between groups with different numbers of respondents. We report the difference between the overall mean for all respondents for a given question (Level 1), and the mean for each group (community, Level 2, or women and non-socios, Level 3). While our sample sizes were not sufficiently large to permit robust inferential statistical analysis, we highlight cases where the group mean differed from the overall mean by $20 \%$ or more as potentially indicative of noteworthy exceptions to the overall trend.

\section{RESULTS}

In terms of respondent demographics, of the 101 respondents, 62 were males and 39 were females. The majority of both males (85\%) and females (67\%) were full community members (socios) (Table 2). Non-socio respondents were an average of 11 years younger than socios (average age of 29 vs. 40 years). In two communities ( $\mathrm{C}$ and $\mathrm{D}$ ), we interviewed only socio members.

\section{Full and effective participation}

We asked six questions to evaluate full and effective participation of individuals at the community level (Fig. 1). The first three questions measured respondents' participation 
in the decision to join Socio Bosque and in the development of the investment plan. The other three questions examined how decisions are made by the community, and if the requirement by Socio Bosque for decisions to be made in communal assemblies is met. Most respondents (81\%) stated that the decision to join PSB was made in community assemblies, and $66 \%$ also said they participated in the decision-making process. A majority (84\%) confirmed that the location of the conservation area was selected in a community assembly. However, less than half (44\%) of respondents reported that the incentives were managed in an assembly, 33\% claimed that the leaders were managing the incentives, and 23\% stated they did not know how incentives were managed. Fewer than half of the respondents knew about the existence of an investment plan (Fig. 1). Of those who knew about the investment plan, about half (20 respondents) said they had participated in the decision about what elements it should include; this represents only $20 \%$ of our overall sample. In two separate questions, most respondents (nearly $80 \%$ ) said their perceived participation in the decision about how to use the Socio Bosque incentives and their perceived level of information about the incentive use was little or nothing (Figs. 2 and 3).

Fig. 2. Perceived participation in the decision-making about Socio Bosque incentives $(N=95)$.

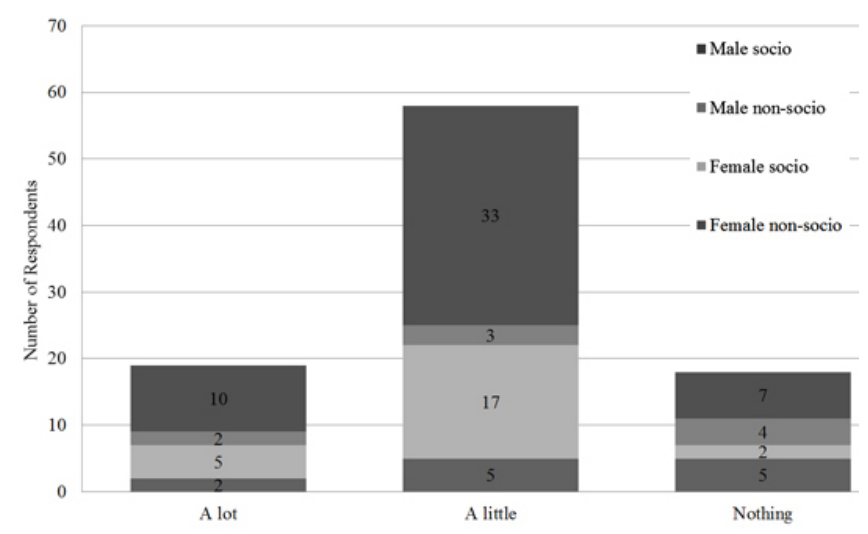

There were differences in how people in different communities responded. Community B was notably low in participation rates for the decision to join PSB (40\%), and none of the respondents had participated in the development of the investment plan. Compared to other communities, fewer respondents in B stated that the decision to join PSB (56\%) and the process to manage incentives $(19 \%)$ were made through the community assembly. Communities D and E had high participation rates; most respondents in Community D (86\%) participated in the decision to join PSB, and $75 \%$ of those who knew about the communal investment plan participated in the decision about what to include in it. In Community E, $82 \%$ of respondents who knew about the existence of the communal investment plan participated in the decision about what to include in the plan.

Fig. 3. Perceived level of information about the Socio Bosque incentives $(N=95)$.

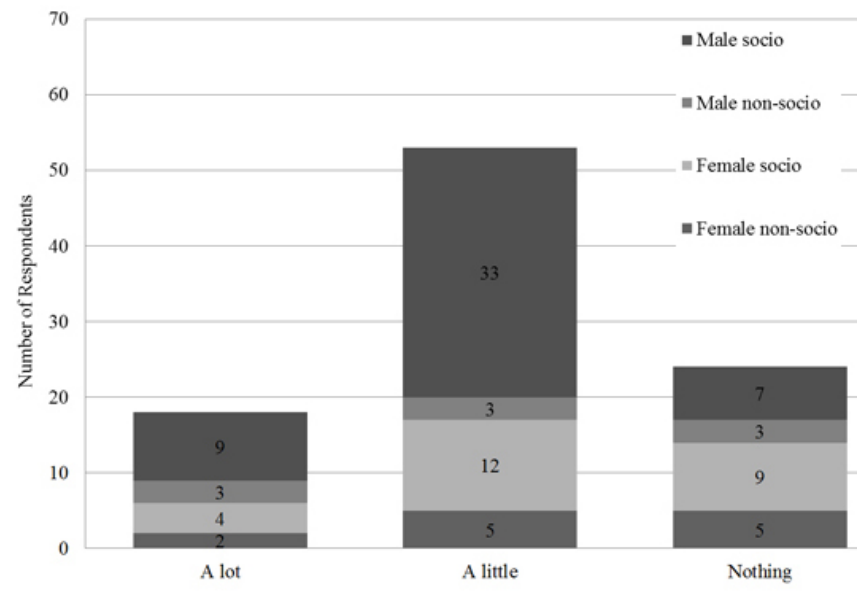

Differences in responses were pronounced for women and non-socios. In general, "Yes" answers from women and nonsocios were below the mean for the first three questions about personal participation but slightly above the overall mean for questions about community institutions (Fig. 1). In Community A, both groups reported low levels of participation in the decision to join PSB (50\% of women and $44 \%$ of non-socios) and in the development of the investment plan (none of the women and $33 \%$ of non-socios). In Communities $\mathrm{B}$ and $\mathrm{C}$, women showed low levels of participation, as did non-socios in Communities B and E. Women's participation was high in Community D, where $100 \%$ had participated in the decision to join PSB, and $67 \%$ knew about the existence of the communal investment plan. Only $13 \%$ of female respondents in Community E knew about the existence of the communal investment plan, but of these, $100 \%$ stated that they had participated in the decision about what to include in the plan.

\section{Free, prior, and informed consent}

Most respondents had a clear picture of the overall goal of Socio Bosque; when asked an open-ended question about what Socio Bosque stands for, the majority (77\%) stated that the program symbolizes forest protection (data not shown). Respondents were aware of conservation values such as biodiversity, and many expressed the wish to conserve the forest for their children's sake. Furthermore, more than $80 \%$ of respondents were familiar with and agreed to the selection of the location of the conservation area (Fig. 4), which was chosen in community assemblies (Fig. 1). The majority of 
Fig. 4. Interview questions and answers related to free, prior, and informed consent for all respondents (Level 1), by individual communities (Level 2), and for women and non-socios within each community (Level 3). The percentages are relative to the number of respondents in that group (i.e., total respondents in each community for Level 2, or total women or non-socios in each community for Level 3). Means across all communities for the total number of women and non-socios are shown in gray columns. The percentages for each group are highlighted in green when $\geq 20 \%$ higher than the global mean (Level 1), or yellow when $\geq 20 \%$ lower than the global mean. Bold font indicates the aggregated "Yes" answers on which the disaggregated answers for each community are based. NA = not applicable.

\begin{tabular}{|c|c|c|c|c|c|c|c|c|c|c|c|c|c|c|c|c|c|c|c|c|c|c|c|}
\hline \multirow{4}{*}{ Question } & \multicolumn{4}{|c|}{ Level 1} & \multicolumn{5}{|c|}{ Level 2} & \multicolumn{14}{|c|}{ Level 3} \\
\hline & \multirow{2}{*}{\multicolumn{4}{|c|}{ All respondents }} & \multicolumn{19}{|c|}{ Only Yes Answers } \\
\hline & & & & & \multicolumn{5}{|c|}{ Community } & \multicolumn{7}{|c|}{ Women } & \multicolumn{7}{|c|}{ Non-socios } \\
\hline & $\mathrm{N}$ & Yes & No & $\begin{array}{l}\text { Don't } \\
\text { know }\end{array}$ & $A$ & B & $\mathrm{C}$ & $\mathrm{D}$ & E & $\mathrm{A}$ & B & C & $\mathrm{D}$ & $\mathrm{E}$ & $\mathrm{N}$ & Yes & $\mathrm{A}$ & B & c & $\mathrm{D}$ & E & $\mathrm{N}$ & Yes \\
\hline $\begin{array}{l}\text { Do you know the terms of } \\
\text { the Socio Bosque } \\
\text { agreement? }\end{array}$ & 99 & $17 \%$ & $83 \%$ & $0 \%$ & $10 \%$ & $16 \%$ & $22 \%$ & $0 \%$ & $27 \%$ & $0 \%$ & $0 \%$ & $0 \%$ & $0 \%$ & $0 \%$ & 37 & $0 \%$ & $0 \%$ & $8 \%$ & $\mathrm{NA}$ & NA & $14 \%$ & 22 & $9 \%$ \\
\hline $\begin{array}{l}\text { For how many years is the } \\
\text { duration of the Socio } \\
\text { Bosque agreement?* (Yes } \\
\text { denotes correct answer) }\end{array}$ & 97 & $39 \%$ & $61 \%$ & $0 \%$ & $53 \%$ & $10 \%$ & $67 \%$ & $43 \%$ & $50 \%$ & $20 \%$ & $9 \%$ & $50 \%$ & $33 \%$ & $44 \%$ & 37 & $27 \%$ & $38 \%$ & $0 \%$ & $\mathrm{NA}$ & NA & $43 \%$ & 21 & $29 \%$ \\
\hline $\begin{array}{l}\text { Do you know how many } \\
\text { hectares the conservation } \\
\text { area has?* (Yes denotes } \\
\text { correct answer) }\end{array}$ & 95 & $30 \%$ & $25 \%$ & $45 \%$ & $70 \%$ & $3 \%$ & $17 \%$ & $17 \%$ & $43 \%$ & $40 \%$ & $0 \%$ & $33 \%$ & $0 \%$ & $25 \%$ & 35 & $20 \%$ & $44 \%$ & $0 \%$ & $\mathrm{NA}$ & NA & $0 \%$ & 21 & $19 \%$ \\
\hline $\begin{array}{l}\text { Do you know the location } \\
\text { of the conservation area?* } \\
\text { (Yes denotes correct } \\
\text { answer) }\end{array}$ & 98 & $83 \%$ & $10 \%$ & $7 \%$ & $90 \%$ & $81 \%$ & $61 \%$ & $100 \%$ & $91 \%$ & $80 \%$ & $75 \%$ & $50 \%$ & $100 \%$ & $78 \%$ & 38 & $76 \%$ & $89 \%$ & $67 \%$ & $\mathrm{NA}$ & $\mathrm{NA}$ & $71 \%$ & 21 & $81 \%$ \\
\hline $\begin{array}{l}\text { Do you agree with the } \\
\text { conservation area that was } \\
\text { chosen? }\end{array}$ & 92 & $81 \%$ & $15 \%$ & $4 \%$ & $90 \%$ & $89 \%$ & $53 \%$ & $86 \%$ & $81 \%$ & $80 \%$ & $90 \%$ & $33 \%$ & $67 \%$ & $67 \%$ & 35 & $74 \%$ & $89 \%$ & $100 \%$ & $\mathrm{NA}$ & $\mathrm{NA}$ & $71 \%$ & 21 & $86 \%$ \\
\hline $\begin{array}{l}\text { Are there community } \\
\text { rules for the management } \\
\text { of the conservation area? }\end{array}$ & 98 & $74 \%$ & $14 \%$ & $12 \%$ & $80 \%$ & $56 \%$ & $94 \%$ & $100 \%$ & $67 \%$ & $90 \%$ & $7 \%$ & $75 \%$ & $100 \%$ & $63 \%$ & 36 & $78 \%$ & $78 \%$ & $50 \%$ & NA & $\mathrm{NA}$ & $67 \%$ & 21 & $67 \%$ \\
\hline $\begin{array}{l}\text { If yes, do you agree with } \\
\text { the rules? }\end{array}$ & 68 & $84 \%$ & $15 \%$ & $1 \%$ & $100 \%$ & $88 \%$ & $64 \%$ & $71 \%$ & $86 \%$ & $100 \%$ & $88 \%$ & $0 \%$ & $67 \%$ & $80 \%$ & 28 & $79 \%$ & $100 \%$ & $100 \%$ & $\mathrm{NA}$ & NA & $50 \%$ & 14 & $86 \%$ \\
\hline
\end{tabular}

The results for this questions were transformed into nominal variables for better presentation and because the area size and location are community dependent.

respondents (74\%) knew about the existence of some form of conservation rules; of these, $84 \%$ agreed with having some form of conservation rules. However, most respondents (83\%) stated they were not familiar with the terms that constitute the Socio Bosque agreement (Fig. 4). When asked about specific details of the Socio Bosque agreement, most respondents $(61 \%)$ did not know the duration of the contract (20 years) or how large the community's area under conservation was (70\%).

In terms of individual communities, respondents throughout the communities expressed little knowledge of the details of the conservation agreement $(17 \%)$, such as its duration and the size of the conservation area. In Community A, responses were close to the overall mean for all questions, while respondents in Community $\mathrm{B}$ answered below the mean for most questions, with only $10 \%$ aware of the duration of the PSB agreement and only 3\% aware of the conservation area size. A sign of a lack of informed consent was that people in Community $\mathrm{C}$ were less aware of the location of the conservation area $(61 \%)$ but also disagreed with the area choice $(53 \%)$, while $94 \%$ knew about conservation rules. For Community D, results were limited by the low sample size $(N$ $=7$ ), but none of the respondents claimed to know the terms of the conservation agreement, while all knew the location of the conservation area and the existence of some form of conservation rules. Community E was within our defined $20 \%$ limit of the overall mean.

Responses for women and non-socios were distinct from the aggregated responses. Although $27 \%$ of the male respondents knew the terms of Socio Bosque (Question 1 in Fig. 4, data not shown), none of the female and only two non-socio respondents did. In Community B, no female or non-socio respondents knew the area size, and both groups showed little knowledge about the existence of some form of conservation rules. In Community C, only $33 \%$ of female respondents knew about the size, and all disagreed with the conservation rules. None of the female respondents in Community D knew the size of the conservation area. In Community E, none of the 
Fig. 5. Interview questions and answers related to equitable, nondiscriminatory, and transparent benefit sharing and distribution for all respondents (Level 1), by individual communities (Level 2), and for women and nonsocios within each community (Level 3). The percentages are relative to the number of respondents in that group (i.e., total respondents in each community for Level 2, or total women or non-socios in each community for Level 3). Means across all communities for the total number of women and non-socios are shown in gray columns. The percentages for each group are highlighted in green when $\geq 20 \%$ higher than the global mean (Level 1), or yellow when $\geq 20 \%$ lower than the global mean. Bold font indicates the aggregated "Yes" answers on which the disaggregated answers for each community are based. NA = not applicable.

\begin{tabular}{|c|c|c|c|c|c|c|c|c|c|c|c|c|c|c|c|c|c|c|c|c|c|c|c|}
\hline \multirow{4}{*}{ Question } & \multicolumn{4}{|c|}{ Level I } & \multicolumn{5}{|c|}{ Level 2} & \multicolumn{14}{|c|}{ Level 3} \\
\hline & \multirow{2}{*}{\multicolumn{4}{|c|}{ All respondents }} & \multicolumn{19}{|c|}{ Only Yes answers } \\
\hline & & & & & \multicolumn{5}{|c|}{ Community } & \multicolumn{7}{|c|}{ Women } & \multicolumn{7}{|c|}{ Non-socios } \\
\hline & $\mathrm{N}$ & Yes & No & $\begin{array}{l}\text { Don't } \\
\text { know }\end{array}$ & $\mathrm{A}$ & B & C & $\mathrm{D}$ & $\mathbf{E}$ & $A$ & B & $\mathrm{C}$ & $\mathrm{D}$ & E & $\mathrm{N}$ & Yes & $\mathrm{A}$ & B & $\mathrm{C}$ & D & $\mathrm{E}$ & $\mathrm{N}$ & Yes \\
\hline $\begin{array}{l}\text { Do you know how much the } \\
\text { community receives per year for } \\
\text { participating in Socio Bosque?* } \\
\text { (Yes denotes correct answer) }\end{array}$ & 98 & $39 \%$ & $14 \%$ & $47 \%$ & $35 \%$ & $41 \%$ & $44 \%$ & $29 \%$ & $38 \%$ & $10 \%$ & $25 \%$ & $25 \%$ & $33 \%$ & $13 \%$ & 37 & $19 \%$ & $11 \%$ & $17 \%$ & NA & $\mathrm{NA}$ & $17 \%$ & 21 & $14 \%$ \\
\hline $\begin{array}{l}\text { Does the participation in Socio } \\
\text { Bosque put any limitations on } \\
\text { your family's activities? (Yes is a } \\
\text { negative answer) }\end{array}$ & 98 & $47 \%$ & $46 \%$ & $7 \%$ & $40 \%$ & $47 \%$ & $50 \%$ & $57 \%$ & $48 \%$ & $30 \%$ & $36 \%$ & $75 \%$ & $67 \%$ & $50 \%$ & 36 & $44 \%$ & $22 \%$ & $50 \%$ & NA & NA & $33 \%$ & 21 & $38 \%$ \\
\hline $\begin{array}{l}\text { Has the community had any } \\
\text { internal conflicts about Socio } \\
\text { Bosque? (Yes is a negative } \\
\text { answer) }\end{array}$ & 97 & $46 \%$ & $47 \%$ & $7 \%$ & $40 \%$ & $42 \%$ & $39 \%$ & $43 \%$ & $67 \%$ & $60 \%$ & $27 \%$ & $50 \%$ & $67 \%$ & $50 \%$ & 36 & $47 \%$ & $22 \%$ & $50 \%$ & NA & NA & $50 \%$ & 21 & $33 \%$ \\
\hline $\begin{array}{l}\text { Does your family receive any } \\
\text { benefit from participating in } \\
\text { Socio Bosque? }\end{array}$ & 98 & $43 \%$ & $57 \%$ & $0 \%$ & $65 \%$ & $6 \%$ & $50 \%$ & $86 \%$ & $57 \%$ & $60 \%$ & $0 \%$ & $25 \%$ & $100 \%$ & $50 \%$ & 38 & $37 \%$ & $33 \%$ & $0 \%$ & NA & NA & $33 \%$ & 21 & $24 \%$ \\
\hline $\begin{array}{l}\text { In your opinion, does the } \\
\text { community have any visible } \\
\text { benefits from participating in } \\
\text { Socio Bosque? }\end{array}$ & 98 & $53 \%$ & $34 \%$ & $13 \%$ & $65 \%$ & $22 \%$ & $50 \%$ & $71 \%$ & $86 \%$ & $60 \%$ & $23 \%$ & $25 \%$ & $67 \%$ & $63 \%$ & 38 & $45 \%$ & $56 \%$ & $0 \%$ & NA & NA & $67 \%$ & 21 & $43 \%$ \\
\hline
\end{tabular}

non-socios knew about the size and $50 \%$ disagreed with the rules that apply to the conservation area.

\section{Equitable, nondiscriminatory, and transparent benefit sharing and distribution}

The majority $(61 \%)$ of respondents did not know the amount of incentives their community receives annually for participating in Socio Bosque (Fig. 5). Just under half of the respondents $(46 \%)$ reported that they had experienced limitations for their families and an increase in community conflicts as a result of the designation of the conservation area and financial mismanagement (Fig. 5). While 43\% stated that their family had received benefits from participating in PSB, $53 \%$ perceived communal benefits, giving examples such as better school equipment, educational scholarships, and communal projects like water tanks.

Differences between communities, genders, and by membership status also persisted regarding indicators for equitable benefit sharing. Community $\mathrm{A}$ fared better than average regarding family and community benefits $(65 \%)$, while few respondents in Community B reported family $(6 \%)$ and community benefits (22\%). Respondents in Community $\mathrm{D}$ likewise reported more than average family benefits $(86 \%)$.
In Community E, $67 \%$ of the respondents reported internal conflicts, but $86 \%$ stated that the community had benefits from participating in Socio Bosque.

Throughout the communities, women and non-socios responded below the average for most questions regarding equitable benefit sharing. Only 1 out of 4 non-socios we interviewed perceived family benefits from participating in Socio Bosque (Question 4 in Fig. 5), whereas for full members, the ratio was 1 out of 2 . These two groups were on average much less informed about the amount of incentives received per year. While it is positive that only $22 \%$ of non-socios in Community A answered that there were family limitations and internal conflict, only $10 \%$ of female respondents in Community A knew the amount of incentives received. In Community B, none of the women and non-socios interviewed reported family benefits, and only $23 \%$ of women stated that there were communal benefits. For Community $\mathrm{C}$, only 1 out of 4 women stated that the community had visible benefits and that there were no family limitations. In Community D, all the women received family benefits but also reported more family limitations (67\%) and conflicts about PSB (67\%). In Community E, respondents reported more community 
conflicts but also more community benefits, while women and non-socios were less aware about how much the community received in incentives.

\section{DISCUSSION}

Most respondents reported that the decision to join Socio Bosque was made democratically, that they were familiar with the conservation goals of Socio Bosque, and that they knew which area their community had selected for conservation. However, only $17 \%$ were familiar with the overall terms of the conservation agreement, implying that they were either not fully informed of, or did not fully understand, what they were consenting to in joining PSB. Although PSB requires a community investment plan to be democratically developed by community members, less than half of respondents were aware of the existence of the investment plan, and fewer than $20 \%$ had participated in its development. The majority of respondents $(61 \%)$ reported that they did not know the amount of incentives that their community currently receives, and a minority of $44 \%$ stated that incentives were managed democratically in communal assemblies. Moreover, although a slight majority (53\%) said they had noticed benefits to the community from participating in Socio Bosque, the majority $(57 \%)$ said their family had not received any benefits. These results demonstrate a need to strengthen inclusive participation, better inform participants about program design, and improve the management of incentives within communities if incentive-based conservation programs are to achieve their social development and environmental goals. The results we present do not constitute a representative sample of each community. However, they represent the first empirical evidence on which future larger-scale studies can be based, and demonstrate the importance of accounting for more marginalized groups, such as women and non-socios.

\section{Inclusive participation}

We examined to what extent individual community members participated in the decision to join Socio Bosque, and once they had joined, to what extent they participated in the decisions regarding how incentives at the community level were used or are going to be used. Our results confirm that the basic democratic structures that give community members the possibility to participate in decision-making exist in the form of assemblies, the formal space where all communal decisions are made (Fig. 1). However, the results reveal that although a majority of respondents participated in the assembly where the decision to join Socio Bosque was made, only a minority knew about the existence of the investment plans, and even fewer participated in the development of the investment plans. Participants commonly felt that the process is not inclusive enough, as captured by the statement from a 46-year-old male respondent and full community member: "Socio Bosque only works for the leaders. The people don't know what it is." Similar perceptions were stated by one-third of respondents who indicated that the leaders are the ones who manage the incentives, and another one-quarter did not know or could not answer when asked about the management process for the incentives. Although the decision-making process through assemblies provides an important platform for democratic decision-making, our results suggest that they are not yet a guarantee for full and effective participation for issues such as incentive use and investment plan design (Fig. 1).

We participated in a number of community assemblies and observed that the increased presence of Socio Bosque staff in communities, which began during 2011, may play an important role in improving participation. The presence of skilled staff taking an active role in facilitating assemblies that are convened to devise the community investment plan, which determines the use of the incentives, may generate a more open space for discussion and dissemination of knowledge about PSB and a more beneficial use of the incentives. It can also encourage the participation of groups who are otherwise less vocal by helping to deflect some power from the leaders and can strengthen the direct participation of marginalized groups, foremost women. But, it is important to ensure that outside ministerial presence in community assemblies does not force a particular agenda and thus undermine communal autonomy and institutions or divert power away from the elected leaders.

Analyzing participation requires the consideration of aspects of community hierarchy and power, defined as the ability to make choices and the processes by which those who have been previously disempowered acquire such an ability (Kabeer 1999). This can be applied on two levels - first, the individuals constituting the community, and second, the community as one entity - then expanding this analysis to a third level of indigenous people as a group. At the individual level, there is a real and perceived restriction on power because the ability to choose how to use communal land is now being restricted for 20 years, while the income from the incentives is unevenly distributed. In the community context we assessed, land is a common good and the socially differentiated costs of conservation (e.g., restricted access to land and resources) are to different degrees dependent on an individual's gender and status within the community. At the communal level, there is an additional economic income through the transfer of Socio Bosque incentives, which presents new opportunities for socioeconomic progress. But to what extent these socioeconomic opportunities at the community level are translated into livelihood improvements at the family level is another matter. The lack of participation and inclusion in our findings indicate that local power structures and community hierarchies might impede full and effective participation.

At a larger scale, indigenous communities collectively represent a marginalized group, and their role in conservation incentive programs like Socio Bosque has been contentious. So far, the involvement of indigenous groups in the design of 
REDD+ has been indirect and weak (Schroeder 2010). The Coordinator of Indigenous Organizations in the Amazon Basin (COICA), an umbrella organization of federations spanning the entire Amazon basin of South America, is apprehensive about the limited participation of indigenous peoples in the design of REDD+ (COICA 2010), which is seen as a failure of governance (Thompson et al. 2011). The Confederación de Nacionalidades Indígenas del Ecuado (CONAIE) is strongly opposed to PSB; it claims that the REDD+ negotiations in Ecuador have been held without their consultation and against their beliefs, and dismisses PSB and REDD+ as a commodification of nature (CONAIE 2011). However, the number of indigenous communities participating in Socio Bosque is steadily increasing (PSB 2011). This signifies a certain divide between the political stance of organizations such as CONAIE, which is strongly opposed to PSB, and the communities that intend to address local needs by participating in PSB (Reed 2011).

\section{Free, prior, and informed consent}

While respondents were generally well-informed about the program's main goal of forest conservation, they lacked knowledge about land use rules for the conservation area as they are stipulated by Socio Bosque, as well as specific information and understanding about key terms of the conservation agreement, such as its duration and the size of the conservation area. There are shortcomings with providing and conveying information about PSB and what signing the conservation agreement entails. Only $17 \%$ of respondents expressed familiarity with the terms of Socio Bosque, showing that access to information was either not adequately provided or information was not fully received and understood by community members at the time of project implementation, which means that people were not in a position to give informed consent. However, since most respondents knew about the conservation area and the rules, and agreed with the rules, it shows that people are not opposed to conservation itself.

None of the women and only two non-socios claimed to be informed about the terms of the conservation agreement (Fig. 4). Our results show that answers for the two marginalized groups were below the average for almost all questions regarding FPIC, although there were substantial differences between the communities. Socio Bosque stipulates that the decision to join the program requires majority voting in a community assembly; our interviews confirmed that this had occurred in most cases. Non-socios are not considered full community members and are thus not allowed to formally vote on important decisions. Consequently, non-socios are left out of decision-making processes, and our results reveal that they have participated less, are less informed, and thus benefit to a lesser degree from the incentives than full community members.
Information about the implications of signing the agreement, which is written in Spanish and signed by the elected representative of the community, is provided in meetings that are conducted in Spanish using technical terms, with infrequent and nonprofessional translation to Kichwa. This prevents community members who lack Spanish language fluency and who do not understand the technical terms, particularly older people and women, from following the meetings with Socio Bosque representatives. This may foster conditions for powerful leaders to drive their own agenda, which was reported in our interviews. In addition to impeding informed consent, the language barrier and the lack of translation represent a barrier to full and effective participation.

We assert that consent should be given regarding the decision to join the program; following this, an important part of being informed is having knowledge of the rules of the program, i. e., rules that apply to the conservation area, area location, and contract duration. Furthermore, it is imperative for a conservation program like Socio Bosque to ensure that local stakeholders are well-informed about the risks and benefits of any decision that affects their livelihoods, rights, and territories to achieve the transparency that provides legitimacy and fairness (Shelton 2007). The contract has a 20-year duration with significant responsibilities and restrictions for land use. Although it is not clear if majority decision-making in assemblies about general issues is a satisfactory level of community consent, it is important that all community members and not just socio men understand the agreement and its terms prior to the implementation of any PES-like project, such as Socio Bosque.

\section{Equitable, nondiscriminatory, and transparent benefit sharing and distribution}

Our results indicate that Socio Bosque does not fully achieve equitable benefit sharing at the community level, i.e., people do not perceive receiving direct benefits or a fair distribution of benefits. Only a little more than half of our respondents perceived some communal benefits from participating in the program, while less than half perceived that the incentives had positive impacts on their family livelihoods, and $80 \%$ claimed that their own participation in the decisions about the incentives was low (Fig. 2). Furthermore, almost two-thirds of respondents did not know how much money their community receives in yearly incentives. If half of a community's population does not perceive family or community benefits from participating in PSB (Fig. 5), we infer that equity in the distribution of benefits is not currently being achieved. In the communities we analyzed, there were no signs of a need-based redistribution of benefits to people that encounter a higher cost associated with the implementation of Socio Bosque. A 32-year-old female respondent reported, "My land is inside the area and they do not give me money," which exemplifies the perceived inequity 
in the benefit distribution. This is especially the case for younger community members, who are often non-socios. They encounter restrictions for new agricultural land since the land they would have received is now a protected area, but they do not get any compensation in return.

While Socio Bosque requires a democratic process to develop a communal investment plan that specifies incentive use up front in order to encourage long-term investments that generate positive outcomes for the communities, there is evidence that some community leaders have abused their position and diverted the conservation incentives for personal enrichment. As a 33-year-old male respondent reported, "The money does not reach the people, the leaders are eating it." In fact, two of the communities (B and E) in this study had their payments suspended in 2012 because of internal conflicts about incentive mismanagement. Problematic participation and benefit sharing that includes women and non-socios has also been reported from Community A (Figs. 1 and 5), which is portrayed as a showcase by the PSB office and occasionally receives international official visitors who are shown how PSB works.

Internal power dynamics in communities that are adjusting resource use behavior to generate new revenues require explicit attention. Our findings suggest that internal decisionmaking processes are contributing to inequitable benefit distribution and internal conflicts, which supports earlier reports that underline difficulties with income distribution in other communities participating in PSB (Pachamama 2010) and with lack of transparency (Rojas et al. 2011). The complications further compound the potential for mismanagement of funds by rent-seeking or inexperienced leaders. Community leaders are elected for an average of two years; this short duration might explain rent-seeking behavior while in a position of power, or simply a lack of knowledge about financial management. Accounting for and understanding the distribution of power among groups within communities is important for the evaluation of social equalities (Lukes 2002) and ultimately for equitable benefit sharing, while respecting internal decision-making processes, selfdetermination, and local governance.

Incentives for conservation can either strengthen communities or "de-communitize" them (West 2006). Almost half of respondents reported increased conflicts after joining Socio Bosque (Fig. 5), the majority of which were over financial management and benefit sharing, which can increase perceived inequities. Defining institutional arrangements for benefit distribution within an indigenous group or community is a delicate matter, but conflicts over the distribution of benefits from a project may represent more of a threat to cultural survival, stability, and functioning of local or traditional community institutions than the implementation of the project itself (Downing and Garcia-Downing 2001). Only if projects are perceived as fair and agreements are reached in a collaborative way can conflict turn into consensus (Peskett 2011). However, Socio Bosque was designed as a classic topdown conservation measure by the Ministry of Environment and a large conservation organization, and did not include a strong participatory approach in the beginning (Chíu 2011, personal communication), which has been criticized by the indigenous groups and organizations in Ecuador.

\section{Reflections and implications on program design}

There is little doubt that incentives are important for conservation (Wunder 2000), and incentives from programs like Socio Bosque are encouraged by the Ecuadorian constitution (República del Ecuador 2008) and funded largely from the government budget. However, framing incentives purely in terms of community economic benefits without providing sufficient capacity building and nonmonetary incentives is too narrow, simplistic, and potentially counterproductive (Berkes 2004). What people in communities value is likely to vary from case to case, but access to resources is almost always important, and any conservation project that closes access to an area or a resource is likely to be opposed, at least by some community members (Berkes 2004). This underlines the importance of equitable benefit distribution if collective community conservation is to be incentivized over the long term. Communities are complex, elusive, and nonhomogeneous (Agrawal and Gibson 1999), and so is the benefit distribution from any conservation project (Berkes 2004). This is a challenge for PSB, since only full members in the communities participate in the decision to join the program through majority voting, which marginalizes those who are not full community members. Furthermore, there are strong indications that vulnerable groups are being marginalized from the economic benefits brought by PSB. Berkes (2004) noted that conservation and development projects that aim to provide community benefits often end up resulting in a less equitable distribution of power and assets, as well as elite capture (Lindhjem et al. 2010). In the long term, there might be a risk that inequity in benefit distribution undermines the environmental effectiveness because people who do not benefit have less reason to respect the conservation area rules.

Socio Bosque has shortcomings regarding full and effective participation, particularly for women and non-socios, who participated less in the decision to join PSB, were less aware of the existence of a communal investment plan, and participated at very low levels in the development of the communal investment plans (Fig. 1). The gender difference we identified is a major shortcoming of program participation, and unfortunately is also shared by other similar projects (Corbera et al. 2007, Gurung and Quesada 2009). Aside from problems with gender inclusion, we highlighted existing differences in participation levels between socios and nonsocios. The question of how to include non-socios has not yet 
been addressed in PSB. This is important because non-socios also bear the costs of conservation and are expected to follow the rules. Incentive use and distribution is being driven by more influential community members, and PSB may be magnifying traditional power inequalities. However, interfering with communal decision-making involves a tradeoff between respecting communal autonomy and internal decision-making processes on one hand, and the imposition of terms and processes to achieve full and effective participation of community members on the other.

\section{CONCLUSION}

While Socio Bosque has achieved impressive success in terms of the area conserved and the number of beneficiaries reached, we identified several potential concerns with the current implementation at the community level. These concerns include low levels of participation in communal decisionmaking about the use of the incentives, a lack of information about the terms of the conservation agreement, and inequitable benefit sharing, including perceived limitations for families and a lack of direct benefits, especially for marginalized groups. These perceptions are challenges for PSB in achieving its social objectives, particularly reducing rural poverty, which could further feed the critique towards the program and similar market-based instruments that are built on the transfer of financial incentives to achieve conservation objectives. Meeting the safeguards of full and effective participation; free, prior, and informed consent; and equitable, nondiscriminatory, and transparent benefit sharing and distribution is challenging, even in a relatively progressive national-level incentive-forconservation program. The challenges with broader governance issues, such as transparency, participation, and benefit distribution within communities, also highlight the dilemma of how much a government-run program like Socio Bosque should interfere with or impose rules of good governance on the internal governance processes in indigenous communities without violating indigenous peoples' rights to self-determination. PSB needs to rethink and be aware of the complexities and hierarchies that operate within communities, which requires a deeper understanding of what people in communities expect from the conservation incentives. Moreover, entrenched local governance institutions can impede the successful implementation of Socio Bosque as an effective and equitable mechanism. Further research is needed to reveal if and how Socio Bosque is altering common property management norms, and if and how this impacts women, non-socios, and other marginalized families.

Socio Bosque is not a REDD+ project and would face challenges in meeting the REDD+ carbon criteria because a full-fledged REDD+ program will require proof of additionality. It is likely that many areas currently conserved would not generate additional emissions reductions because their remoteness decreases accessibility for logging, or because they were previously a community forest reserve. However, transaction and implementation costs in Socio Bosque are borne largely by the Ministry of Environment, and local communities are for the first time in a position to manage relatively substantial economic resources themselves. The approach taken by Socio Bosque directly rewards communities that have protected their forests, cuts out intermediaries, and provides financial support for conservation (Reed 2011). This can be seen as a more straightforward approach compared to current REDD+ proposals where additionality is a main design feature, which can create perverse incentives where only areas with a high risk of deforestation are included, thereby presenting a disadvantage to communities that have been protecting their forests (Angelsen and Wertz-Kanounnikoff 2008). Thus, although PSB is facing various challenges that need to be addressed, the program represents a first step for effective conservation that is driven by communities.

Our findings are based on individual perceptions that arise from collective decision-making processes, which point to problems at the local level. Although the focus on individual community members limits our analysis in its scope, it nevertheless reveals the need for caution by project staff and policy-makers who may see their responsibility ending once they have spoken to democratically elected leaders or once a decision has been made by the community assembly. Involving local people and paying close attention to how individual community members perceive conservation interventions is a fundamental requirement for inclusive conservation. Focusing on the individual level is necessary to ensure participation and consent but is not sufficient to address power asymmetries that arise in collective decision-making at the community level, as well as other, larger interests at the regional, national, and international level. These larger interests are likely to be more prevalent in future REDD+ project areas that are chosen for their high threat of deforestation, which will be subject to greater external pressures and internal or community politics. It is especially important for policy-makers to make sure safeguards can be met in these areas.

Based on our results, we close by suggesting improvement to PSB, which can also be valuable for similar projects beyond the borders of Ecuador. While high rates of participation were reported in the decision to join Socio Bosque, we assert that fully informed consent requires ongoing participation, including solid knowledge of the terms of the program and the process for managing the incentives it generates. The present low awareness of the terms of the program and the management of incentives indicates a need for more community involvement throughout the program, not just at the beginning. Several respondents expressed the wish for more workshops and information meetings in the local language to be held directly in the communities to encourage 
active participation, not only by community representatives but also by marginalized groups, such as women and nonsocios. In addition to providing better access to important and relevant information prior to and throughout the implementation of the program, this would help to remove one of the barriers impeding full and effective participation. Improved community participation and the newly implemented socioeconomic monitoring by Socio Bosque staff are ways to respond to existing or potential conflicts within communities in a timely manner and to establish relations based on trust and mutual respect rather than a mere policing presence. However, the presence of staff must not lead to coercion or community policing but should maintain a mediating and capacity building function.

Translating the conservation agreements and the requirements for community management of incentives into the local languages is a step to achieve informed consent and better reach community members who are about to decide whether or not to join Socio Bosque. Every family should receive a copy of the agreement prior to voting in the assembly about joining PSB. Although this comes at a higher initial cost to Socio Bosque, it better addresses the safeguards for FPIC and can reduce the risk of community conflict and elite capture in the long run, which also increases the legitimacy of the conservation project. Such improvements are necessary to ensure both the social equity and the conservation effectiveness of incentive-based programs such as Socio Bosque.

Responses to this article can be read online at: http://www.ecologyandsociety.org/issues/responses. php/5733

\section{Acknowledgments:}

We are grateful to all the people in the communities who took the time and made the effort to participate in the interviews, making this research possible. The authors would like to thank the staff at the Ministry of Environment for their support during the research process. Further acknowledgments go to Paola Onofa and Silverio Mamallacta for their support while conducting interviews in the communities and our colleagues in LUCID, particularly Mine Islar, for commenting on earlier versions. The paper benefited greatly from two anonymous reviewers who provided constructive comments.

\section{LITERATURE CITED}

Achard, F., H. D. Eva, P. Mayaux, H.-J. Stibig, and A. Belward. 2004. Improved estimates of net carbon emissions from land cover change in the tropics for the 1990s. Global Biogeochemical Cycles 18.
Agrawal, A., and C. C. Gibson. 1999. Enchantment and disenchantment: the role of community in natural resource conservation. World Development 27:629-649. http://dx.doi. org/10.1016/S0305-750X(98)00161-2

Anderson, P. 2011. Free, prior, and informed consent in REDD+: principles and approaches for policy and project development. REDOFTC and GIZ, Bangkok, Thailand.

Angelsen, A., M. Brockhaus, W. D. Sunderlin, and L. V. Verchot. 2012. Analysing REDD+: challenges and choices. Center for International Forestry Research (CIFOR), Bogor, Indonesia.

Angelsen, A., and S. Wertz-Kanounnikoff. 2008. What are the key design issues for REDD and the criteria for assessing options? Pages 11-21 in A. Angelsen, editor. Moving ahead with REDD: issues, options and implications. Center for International Forestry Research (CIFOR), Bogor, Indonesia.

Armsworth, P. R., K. M. A. Chan, G. C. Daily, P. R. Ehrlich, C. Kremen, T. H. Ricketts, and M. A. Sanjayan. 2007. Ecosystem-service science and the way forward for conservation. Conservation Biology 21:1383-1384. http://dx. doi.org/10.1111/j.1523-1739.2007.00821.x

Becker, M. 2010. Correa, indigenous movements, and the writing of a new constitution in Ecuador. Latin American Perspectives 38:47-62. http://dx.doi.org/10.1177/0094582X10384209

Benavides, M. 2009. Economía indigena y bosque Amazónico. In Proceedings of the Encuentro Internacional de Pueblos indígenas y Lideres Locales para la Defensa de Derechos y Conservacíon de Bosques, Lima, Peru.

Berkes, F. 2004. Rethinking community-based conservation. Conservation Biology 18:621-630. http://dx.doi.org/10.1111/ j.1523-1739.2004.00077.x

Bertzky, M., C. Ravilious, A. L. Araujo Navas, V. Kapos, D. Carrión, M. Chíu, and B. Dickson. 2010. Carbon, biodiversity and ecosystem services: exploring co-benefits-Ecuador. UNEP-WCMC, Cambridge, UK.

Bremner, J., and F. Lu. 2006. Common property among indigenous peoples of the Ecuadorian Amazon. Conservation and Society 4:22.

Busch, J., F. Godoy, W. R. Turner, and C. A. Harvey. 2010. Biodiversity co-benefits of reducing emissions from deforestation under alternative reference levels and levels of finance. Conservation Letters 4:101-115. http://dx.doi. org/10.1111/j.1755-263X.2010.00150.X

Caplow, S., P. Jagger, K. Lawlor, and E. Sills. 2011. Evaluating land use and livelihood impacts of early forest carbon projects: lessons for learning about REDD+. Environmental Science \& Policy 14:152-167. http://dx.doi. org/10.1016/j.envsci.2010.10.003 
Chíu, M., and D. Carríon. 2011. National programme document Ecuador. UN-REDD, Da Lat, Viet Nam.

Climate, Community \& Biodiversity Alliance and Cooperative for Assistance and Relief Everywhere (CCBA and CARE). 2010. REDD+ Social \& Environmental Standards. Climate, Community \& Biodiversity Alliance and Cooperative for Assistance and Relief Everywhere.

Confederación de Nacionalidades Indígenas del Ecuado (CONAIE). 2011. Cuarto Congreso de los Pueblos y Nacionalidades Indigenas del Ecuador. Confederación de Nacionalidades Indígenas del Ecuado, Puyo, Ecuador.

Coordinadora De Las Organizaciones Indígenas De La Cuenca Amazonica (COICA). 2010. Posicion politica de COICA sobre REDD+. Coordinadora De Las Organizaciones Indígenas De La Cuenca Amazonica, Quito, Ecuador.

Corbera, E. 2012. Problematizing REDD+ as an experiment in payments for ecosystem services. Current Opinion in Environmental Sustainability 4:612-619. http://dx.doi. org/10.1016/j.cosust.2012.09.010

Corbera, E., N. Kosoy, and M. Martínez Tuna. 2007. Equity implications of marketing ecosystem services in protected areas and rural communities: case studies from MesoAmerica. Global Environmental Change 17:365-380. http:// dx.doi.org/10.1016/j.gloenvcha.2006.12.005

Corbera, E., and H. Schroeder. 2011. Governing and implementing REDD+. Environmental Science \& Policy 14:89-99. http://dx.doi.org/10.1016/j.envsci.2010.11.002

Costenbader, J. 2009. Legal frameworks for REDD. Design and implementation at the national level. IUCN, Gland, Switzerland.

Costenbader, J. 2011. REDD+ benefit sharing: a comparative assessment of three national policy approaches. UN-REDD \& Forest Carbon Partnership Facility - FCPF.

Daviet, F., M. Mabel, and E. Halverson. 2011. A draft framework for sharing approaches for better multistakeholder participation practices. Forest Carbon Partnership Facility \& UN-REDD.

de Koning, F., M. Aguiñaga, M. Bravo, M. Chiu, M. Lascano, T. Lozada, and L. Suarez. 2011. Bridging the gap between forest conservation and poverty alleviation: the Ecuadorian Socio Bosque Program. Environmental Science \& Policy 14:531-542. http://dx.doi.org/10.1016/j.envsci.2011.04.007

Downing, T. E., and C. Garcia-Downing. 2001. Plan B: What is going to happen to my people? Cultural Survival Quarterly.

Engel, S., S. Pagiola, and S. Wunder. 2008. Designing payments for environmental services in theory and practice: an overview of the issues. Ecological Economics 65:663-674. http://dx.doi.org/10.1016/j.ecolecon.2008.03.011
Finer, M., C. N. Jenkins, S. L. Pimm, B. Keane, and C. Ross. 2008. Oil and gas projects in the western Amazon: threats to wilderness, biodiversity, and indigenous peoples. Plos One 3: e2932. http://dx.doi.org/10.1371/journal.pone.0002932

Food and Agricultural Organization (FAO). 2011. Forests and poverty reduction. Food and Agricultural Organization, Rome, Italy.

Forest Carbon Partnership Facility (FCPF). 2011. Introduction to the Forest Carbon Partnership Facility. World Bank, Washington, D.C., USA.

Forest Carbon Partnership Facility (FCPF) and UN-REDD. 2011. Guidelines on stakeholder engagement in REDD+ readiness with a focus on the participation of indigenous peoples and other forest dependent communities. Forest Carbon Partnership Facility \& UN-REDD Programme.

Gibbs, H. K., S. Brown, J. O. Niles, and J. A. Foley. 2007. Monitoring and estimating tropical forest carbon stocks: making REDD a reality. Environmental Research Letters 2:045023. http://dx.doi.org/10.1088/1748-9326/2/4/045023

Gray, C. L., R. E. Bilsborrow, J. L. Bremner, and F. Lu. 2007. Indigenous land use in the Ecuadorian Amazon: a crosscultural and multilevel analysis. Human Ecology 36:97-109. http://dx.doi.org/10.1007/s10745-007-9141-6

Gurung, J. D., and A. Quesada. 2009. Gender-differentiated impacts of REDD to be addressed in REDD social standards. Women Organizing for Change in Agriculture and Natural Resource Management (WOCAN), CARE International, Climate, Community and Biodiversity Alliance (CCBA).

Herbertson, K., A. R. Ballesteros, R. Goodland, and I. Munilla. 2009. Breaking ground: engaging communities in extractive and infrastructure projects. World Resources Institute, Washington, D.C., USA. http://dx.doi.org/10.1037/e587702011-001

Hufty, M., and A. Haakenstad. 2011. Reduced Emissions for Deforestation and Degradation: a critical review. Consilience: The Journal of Sustainable Development 5:1-24.

Instituto Nacional de Estadística y Censos (INEC). 2010. Ecuador en Cifras-Nacionalidades y Pueblos. Instituto Nacional de Estadística y Censos. [online] URL: http://www. ecuadorencifras.com/cifras-inec/nacionalidades.html\#tpi=493

International Tropcial Timber Organization (ITTO). 2009. Tropical forest tenure assessment-trends, challenges and opportunities. Rights and Resource Initiative \& International Tropcial Timber Organization, Washington, D.C., USA and Yokohama, Japan.

Jones-Walters, L., and I. Mulder. 2009. Valuing nature: the economics of biodiversity. Journal for Nature Conservation 17:245-247. http://dx.doi.org/10.1016/j.jnc.2009.06.001 
Kabeer, N. 1999. Resources, agency, achievements: reflections on the measurement of women's empowerment. Development and Change 30:435-464. http://dx.doi. org/10.1111/1467-7660.00125

Krause, T., and L. Loft. 2013. Benefit distribution and equity in Ecuador's Socio Bosque Program. Society and Natural Resources. http://dx.doi.org/10.1080/08941920.2013.797529

Lindhjem, H., I. Aronsen, K. G. Bråten, and A. Gleinsvik. 2010. Experiences with benefit sharing: issues and options for REDD-plus. Pöyry, Oslo, Norway.

Lu, F. 2006. 'The Commons' in an Amazonian context. Social Analysis 50:187-194. http://dx.doi.org/10.3167/015597706780459412

Lukes, S. 2002. Power and agency. British Journal of Sociology 53:491-496. http://dx.doi.org/10.1080/00071310$\underline{22000000617}$

Luttrell, C., L. Loft, M. F. Gebara, and D. Kweka. 2012. Who should benefit and why? Discourses on REDD+ benefit sharing. Pages 129-152 in A. Angelsen, M. Brockhaus, W. D. Sunderlin, and L. V. Verchot, editors. Analysing REDD+: challenges and choices. Center for International Forestry Research (CIFOR), Bogor, Indonesia.

McAfee, K., and E. N. Shapiro. 2010. Payments for ecosystem services in Mexico: nature, neoliberalism, social movements, and the state. Annals of the Association of American Geographers 100:579-599. http://dx.doi.org/10.1080/00045$\underline{601003794833}$

McDermott, C. L., L. Coad, A. Helfgott, and H. Schroeder. 2012. Operationalizing social safeguards in REDD+: actors, interests and ideas. Environmental Science \& Policy 21:6372. http://dx.doi.org/10.1016/j.envsci.2012.02.007

Mena, C., A. Barbieri, S. Walsh, C. Erlien, F. Holt, and R. Bilsborrow. 2006. Pressure on the Cuyabeno Wildlife Reserve: development and land use/cover change in the northern Ecuadorian Amazon. World Development 34:18311849. http://dx.doi.org/10.1016/j.worlddev.2006.02.009

Merger, E., M. Dutschke, and L. Verchot. 2011. Options for REDD+ voluntary certification to ensure net GHG benefits, poverty alleviation, sustainable management of forests and biodiversity conservation. Forests 2:550-577. http://dx.doi. org/10.3390/f2020550

Millennium Ecosystem Assessment (MEA). 2005. Ecosystems and human well-being: biodiversity synthesis. World Resources Institute, Washington, D.C., USA.

Ministerio del Medio Ambiente del Ecuador (MAE). 2008. Acuerdo $N^{o} 177$. Ministerio del Medio Ambiente del Ecuador, Quito, Ecuador.
Ministerio del Medio Ambiente del Ecuador (MAE). 2009. Acuerdo $N^{o} 115$. Ministerio del Medio Ambiente del Ecuador, Quito, Ecuador.

Ministerio del Medio Ambiente del Ecuador (MAE). 2011. REDD+ en Ecuador. Una Oportunidad para Mitigar el Cambio Climatico y Contribuir a la Gestion Sostenible de los Bosques. Ministry of Environment of Ecuador, Quito, Ecuador.

Ministerio del Medio Ambiente del Ecuador (MAE). 2012. REDD+ readiness in Ecuador. Ministry of Environment of Ecuador, Quito, Ecuador.

Mittermeier, R. A., C. G. Mittermeier, T. M. Brooks, J. D. Pilgrim, W. R. Konstant, G. A. B. da Fonseca, and C. Komros. 2003. Wilderness and biodiversity conservation. PNASProceedings of the National Academy of Sciences of the United States of America 100:10309-10313. http://dx.doi.org/10.1073/ pnas. 1732458100

Moss, N., and R. Nussbaum. 2011. A review of three REDD+ safeguard initiatives. Forest Carbon Partnership Facility FCPF; UN-REDD Programme.

Myers, N. 1988. Threatened biotas: "hot spots" in tropical forests. The Environmentalist 8:187-208. http://dx.doi. org/10.1007/BF02240252

Myers, N., R. A. Mittermeier, C. G. Mittermeier, G. A. B. da Fonseca, and J. Kents. 2000. Biodiversity hotspots for conservation priorities. Nature 403:853-858.

Nelson, A., and K. M. Chomitz. 2009. Protected area effectiveness in reducing tropical deforestation-a global analysis of the impact of protection status. The World Bank, Washington D.C., USA.

Pachamama. 2010. El dilemma de los bosques en el Ecuador. Fundacíon Pachamama, Quito, Ecuador.

Pagiola, S. 2008. Payments for environmental services in Costa Rica. Ecological Economics 65:712-724. http://dx.doi. org/10.1016/j.ecolecon.2007.07.033

Pearce, D. 2005. Paradoxes in biodiversity conservation. World Economics 6:57-69.

Pearce, D. 2007. Do we really care about biodiversity? Environmental and Resource Economics 37:313-333.

Persson, U., and C. Azar. 2007. Tropical deforestation in a future international climate policy regime-lessons from the Brazilian Amazon. Mitigation and Adaptation Strategies for Global Change 12:1277-1304. http://dx.doi.org/10.1007/ s11027-006-9052-7 
Peskett, L. 2011. Benefit sharing in REDD+: exploring the implications for poor and vulnerable people. World Bank and REDD-net.

Phelps, J., E. L. Webb, and A. Agrawal. 2010. Does REDD+ threaten to recentralize forest governance? Science 328:312313. http://dx.doi.org/10.1126/science.1187774

Pistorius, T. 2012. From RED to REDD+: the evolution of a forest-based mitigation approach for developing countries. Current Opinion in Environmental Sustainability 4:638-645. http://dx.doi.org/10.1016/j.cosust.2012.07.002

Programa Socio Bosque (PSB). 2011. Resultados globales 2011. Programa Socio Bosque, Ministerio del Ambiente del Ecuador, Quito, Ecuador.

Reed, P. 2011. REDD+ and the indigenous question: a case study from Ecuador. Forests 2:525-549. http://dx.doi. org/10.3390/f2020525

República del Ecuador. 2008. Constitución de 2008. República del Ecuador, Quito, Ecuador.

Ricketts, T. H., B. Soares-Filho, G. A. B. da Fonseca, D. Nepstad, A. Pfaff, A. Petsonk, A. Anderson, D. Boucher, A. Cattaneo, M. Conte, K. Creighton, L. Linden, C. Maretti, P. Moutinho, R. Ullman, and R. Victurine. 2010. Indigenous lands, protected areas, and slowing climate change. PLoS Biology 8:e1000331. http://dx.doi.org/10.1371/journal.pbio.1000331

Rojas, C., G. Minango, G. Galarza, R. Gallardo, and J. C. Rojas. 2011. Resultados de la Evaluacion a Socio Communitarios. Socio Bosque \& Ministerio del Ambiente, Quito, Ecuador.

Schroeder, H. 2010. Agency in international climate negotiations: the case of indigenous peoples and avoided deforestation. International Environmental Agreements: Politics, Law and Economics 10:317-332. http://dx.doi. org/10.1007/s10784-010-9138-2

SENPLADES. 2009. Plan Nacional Para el Buen Vivir2009-2013. Secretaria Nacional de Planificacion y Desarollo, Quito, Ecuador.

Shelton, D. 2007. Equity. Pages 639-662 in D. Bodanksy, J. Brunnée, and E. Hey, editors. The Oxford handbook of international environmental law. Oxford University Press, Oxford, UK.

Shvidenko, A., C. V. Barber, R. Persson, P. Gonzalez, R. Hassan, P. Lakyda, I. McCallum, S. Nilsson, J. Pulhin, B. van Rosenburg, and B. Scholes. 2005. Forest and woodland systems. Pages 585-621 in Ecosystems and human well-being: current state and trends. Millennium Ecosystem Assessment, London, UK.
Skutsch, M., and P. E. Van Laake. 2008. REDD as multi-level governance in-the-making. Energy \& Environment 19:831844. http://dx.doi.org/10.1260/095830508785363622

Stern, M., and B. S. Kernan. 2011. Report on biodiversity and tropical forests in Ecuador. United States Agency for International Development, Washington, D.C., USA.

The Economics of Ecosystems and Biodiversity (TEEB). 2010. Mainstreaming the economics of nature: a synthesis of the approach, conclusions and recommendations of TEEB.

Thompson, M. C., M. Baruah, and E. R. Carr. 2011. Seeing REDD+ as a project of environmental governance. Environmental Science \& Policy 14:100-110. http://dx.doi. org/10.1016/j.envsci.2010.11.006

UN-REDD. 2011. UN-REDD Programme Social and Environmental Principles and Criteria, Version 3 draft for consultation. UN-REDD Programme.

United Nations Framework Convention on Climate Change (UNFCCC). 2011. Decisions adopted by the Conference of the Parties-Decision 1/CP.16. United Nations Framework Convention on Climate Change.

United States Agency for International Development (USAID). 2012. Forest Carbon, Markets and Communities (FCMC) Program. Key findings and opportunities for REDD+ in Ecuador. United States Agency for International Development, Burlington, Vermont, USA.

Van Dam, C. 2011. Indigenous territories and REDD in Latin America: opportunity or threat? Forests 2:394-414.

van der Werf, G. R., D. C. Morton, R. S. DeFries, J. G. J. Olivier, P. S. Kasibhatla, R. B. Jackson, G. J. Collatz, and J. T. Randerson. 2009. $\mathrm{CO}_{2}$ emissions from forest loss. Nature Geoscience 2:737-738. http://dx.doi.org/10.1038/ngeo671

Visseren-Hamakers, I. J., C. McDermott, M. J. Vijge, and B. Cashore. 2012. Trade-offs, co-benefits and safeguards: current debates on the breadth of REDD+. Current Opinion in Environmental Sustainability 4:646-653. http://dx.doi. org/10.1016/j.cosust.2012.10.005

West, P. 2006. Conservation is our government now-the politics of ecology in Papua New Guinea. Duke University Press, Durham, NC, USA.

Wunder, S. 2000. Ecotourism and economic incentives-an empirical approach. Ecological Economics 32:465-479. http://dx.doi.org/10.1016/S0921-8009(99)00119-6

Wunder, S. 2005. Payments for environmental services: some nuts and bolts. Center for International Forestry Research (CIFOR), Bogor, Indonesia. 